\title{
CRITERIA OF EXCELLENCE IN THE HUMANITIES ${ }^{1}$
}

\author{
PETAR BAGARIĆ \\ Institute of Ethnology and Folklore Research, Zagreb
}

\begin{abstract}
Originally, excellence in the humanities used to be seen as an agonistic and patrician virtue which relies on the Promethean hybris of the subject of the humanities. This hero of the spirit was supposed to embody the highest human virtues (as seen through the liberal civilizational prism): cosmopolitism, liberalism, philanthropy. However, the present-day meaning and use of the term excellence is determined by the idea of quality developed in organizational sciences, and, in addition to being invoked by corporations, it is also referred to by governments and ministries. The idea is based on the assumption that the quality of the product primarily depends on the organization of the work process. Therefore, the criterion of fulfilling organizational demands (such as the demand for networking, recognizability, dissemination, etc.) is imposed on the humanities as fundamental. In this situation, the hero of the spirit gives way to the end user as the dominant figure driving the rhetoric of corporate excellence. Thus, the humanities find themselves in a position where communication with the socially predominant, corporate-centered, paradigm is difficult.
\end{abstract}

Keywords: the hero of the spirit, the humanities, excellence, end user

\section{INTRODUCTION}

In Croatia, just like in the other countries of the European Union, "scientific excellence" became the key phrase around which scientific policy is organized and individual and collective scientific contributions are evaluated. It is the main goal that scientific institu-

${ }^{1}$ This article is to appear in the edited volume entitled Stranputice humanistike (Bypaths of the Humanities) (Institute of Ethnology and Folklore Research, 2017), and is published here with the permission of the volume editors. 
tions must reach, ${ }^{2}$ and the main criterion which determines the status of an individual in the scientific system. For instance, in 2013, the Croatian Ministry of Science, Education and Sports employed 20 research assistants who fulfilled the highest criteria of excellence. Interestingly, these criteria, whose purpose was to "improve the quality of scholarly and teaching activities in the Republic of Croatia" ${ }^{3}$ did not exist until the positions were advertised. They were not defined until 2013, and were based on the Ministry compiling excellence criteria propositions submitted to them by the universities and public scientific institutes whose very research assistants applied for the positions.

The Ministry's insistence on selecting "excellent candidates" and the willingness of the academic community to participate in creating and defining excellence criteria implies a logic of excellence that science in Croatia is increasingly becoming subject to. Thanks to excellence-based evaluations, which will, according to some announcements, serve as the basis of ranking that will determine funding, and, consequently, the survival of scientific institutions, excellence became of existential import to the everyday life and work of scientists in Croatia. Although largely present in the lives of humanist scholars, the logic of excellence itself is difficult to understand for them, unless subjected to criticism based on the humanities-related categories of gender, class and/or race. Thus, excellence is seen as a male-articulated value (cf. Lynch et al. 2013: 281) which reproduces class, gender and racial dispositions (cf. Bauer and Vrasti 2016) and which is used as an attempt to legitimize social inequality (cf. Katunarić 2013: 27).

However, what we can today imagine as the humanities has been inherited from modernism in interaction with other modernist phenomena, such as class and nation, and within the same temporal framework, which makes it easier for the humanities to understand and criticize these phenomena. Excellence, which is the main topic of this text, on the other hand, does not belong to this heritage, and its meaning is developed outside of modernist value driven disputes. The origin of today's ideal of excellence is in the scientific disciplines dealing with the issues of work and processual organization. Consequently, in Croatian organizational sciences, as opposed to the humanities, excellence is an accepted and recognized topic (cf. Oslić 2008; Sisek 2012), which is visible from, among other things, the scholarly journal Poslovna izvrsnost (Business excellence) started and published by the Faculty of Economics and Business in Zagreb.

\footnotetext{
${ }^{2}$ Excellence is already part of the declared scientific policy. In 2013, the Ministry of Science, Education and Sports, currently the main body funding science in Croatia, published the "Strateški plan zarazdoblje 2014.-2016." (Strategic plan for the period 2014-2016; public.mzos.hr/fgs.axd?id=20740), designed as a means to achieve scientific excellence and ensure quality in the education and science system. The new strategic plan "Nove boje znanja: strategija obrazovanja znanosti i tehnologije" (New colors of knowledge: the strategy of education, science and technology; 2015), places emphasis on excellence, using expressions such as "excellent science", "scientific excellence", "excellent researchers and innovators" (http://www. novebojeznanja.hr/UserDocsImages/datoteke/KB_web.pdf).

3 "Promemorijaodabiranajuspješnijihznanstvenihnovaka" (Memorandum on the selection of the most excellent research assistants; public.mzos.hr/fgs.axd?id=19630).
} 
Business culture of excellence has been imported from the Anglo-Saxon world; it is closely connected with the ideas about the quality of the product and the work process, and has acquired its current form due to the changes in organizational paradigms that have swept over the Western world in the 1980s. This is the period when, in the West, "quality gurus" promoted new organizational models that were supposed to enable western business organizations to respond to the increasing global domination of Japanese manufacturing that were gradually threatening American dominance on the global level. Given that the quality of Japanese products became the main explanation for the global competitiveness of their industry, new organizational concepts introducing an organic approach to work organization became particularly popular.

An organic approach is expected to enable better communication and coordination between employees, to support their commitment to the collective and their efforts in improving quality and putting an end to a mechanistic approach to organization of work, based on control and monitoring of the work process (cf. Baković 2010). In the USA, new quality doctrines gained impetus together with the "excellence reform" in American schools, which was supposed to ensure a professional workforce for the new type of economy. The "gurus" generally agree that improvements need to be made on all levels, rather than only in the form of the final product, that most quality-related problems boil down to management procedures and strategies, that the new approach can be implemented in any organization, and that quality improvement must be a continual activity (cf. Suarez 1992: 2-17). Continual interconnections between all parts and phases of the organization process are required, constant evaluation and self-evaluation is introduced, and the focus changes from product inspection to the inspection of the manufacturing process; worker dedication is called for, and managers are encouraged to take on responsibility.

These new organizational teachings profile the term "quality" as an indication of successful organizational structure and a well-designed work process; new ideas about quality increasingly enter the public sphere (cf. Giroux and Landry 1998) and become part of public institution policies:

quality has become an immensely popular term where the organization of public services is concerned. It is on the lips of politicians, managers, professional and citizens themselves. In health care, education, personal social services, fire services, the police, and many other subsectors, commitments are being made to improve quality and increase responsiveness to the customers (clients/patients/students/users). Brochures and booklets are being issued, reports are being written, training courses are being delivered; quality has become a central term in our contemporary rhetoric. It is scarcely conceivable that anyone would wish to argue against it: like virtue, it seems unopposable. (Pollitt and Bouckaert 1995: 3)

\footnotetext{
${ }^{4}$ In the more recent literature about quality within organizational sciences, "guru" is a technical term that is used to refer to the initiators of the new organizational paradigms: William Edwards Deming, Joseph Moses Juran, Phillip B. Crosby, Claus Møller and Armand V. Feigenbaum.
} 
The introduction of new ways to improve quality into the public sector is aided by the fact that Total Quality Management (TQM), one of the more prominent and popular approaches to quality improvement in the public sector, originated within state institutions. In fact, in the early 1980s, US Navy adopted Deming's rules about quality in order to improve its operative efficiency, and on the basis of the project, branded TQM (cf. Houston and Dockstader 1997) in 1985, which was later implemented in various parts of public administration.

In Europe, new ideas enteredthe public administration primarily through the central institutions of the European Union. In 1989, the European Commission encouraged the creation of the European Foundation for Quality Management (EFQM), ${ }^{5}$ which, on the basis of TQM ideas, developed the CAF model (cf. Pollit and Bouckaert 2004: 233-234) of quality improvement in public administration. ${ }^{6}$ In addition to EFQM and CAF, The European Union also had ISO, The International Organization for Standardization, an international organization issuing certificates of quality to private and public institutions, at its disposal. Moreover, there is ENQA, the European Association for Quality Assurance in Higher Education, which develops common criteria and norms of European quality assurance in cooperation with autonomous subjects, such as agencies. Although it lacks classical features of state ideology that are guaranteed by state enforcement bodies, quality assurance is a compulsory process that is controlled and monitored by the state (cf. Dolaček-Alduk et al.). ${ }^{8}$ The requirement to improve the quality of services provided by public institutions has become a general trend in the EU, ${ }^{9}$ and the process of accession of new members serves as an opportunity to import new management techniques (Matei and Lazăr 2011: 94). ${ }^{10}$

By being introduced into state institutions, the logic of quality gets new impetus, and feeds back into the private sector. Both American and European private companies from small-scale family farms to big corporations - frequently have the opportunity to compete for funds or jobs that require a certain level and a certain form of "quality" as

${ }^{5}$ http://www. Efqm. Org/about-us/our-history.

${ }^{6}$ http://www. Eipa. Eu/en/topic/show/\&tid=191.

7 To coordinate with the ENQA, the governments of European Union member countries establish independent agencies, whose aim is to evaluate, accredit and improve the quality in the educational and scientific system, as well as to distribute funds based on competitions for scientific projects (http://www. enqa.eu/index.php/enqa-agencies/members/full-members/). In Croatia, this role is played by ASHE Agency for Science and Higher Education (https://www.azvo.hr/en/about-ashe).

8 "Autonomous subjects are required to act in accordance with the established norms, whereby ENQA is in charge of control, universities of application, and the state of supervision (Dolaček-Alduk et al. 2008: 40).

${ }^{9}$ Klaus Welle, Secretary General of the European Parliament, in his speech at the Association of European Chambers of Commerce and Industry Conference in 2014, advocated the idea that the problems of European legislature should be solved based on TQM principles (http://www.europarl.europa.eu/ the-secretary-general/en/total-quality-management-along-the-whole-legislative-cycle-a-fresh-look-atbetter-law-making).

${ }^{10}$ In 2009, The Croatian Parliament passed a law concerning quality assurance in science and higher education, with the aim "to constantly improve processes and their outcomes" (https://www.azvo.hr/images/stories/o_nama/Zakon.pdf). 
a precondition to take part in the tender, which favors further dissemination of TQM-like models through consultations, seminars, etc. Systematic efforts to improve quality - which primarily means accepting an organic approach to the work process - promote an ideal determined to be the purpose and goal of all organization endeavors, i.e. excellence.

This text will present certain organizational procedures and changes in schooling in the USA, which is where the new paradigm, the basis of the established discourse of excellence, first appeared. Organizational practices and changes in education and science will be seen as cultural practices (cf. de Guy 2000: 166). These practices give meaning to -new "metaphysics" of - work and the subject, with the rhetoric of excellence and quality providing Levi-Straussian symbolic effectiveness (cf. Levi-Strauss 1963). The rhetoric in question, in fact, is a way to explain the causes and consequences of the phenomenon, and ensures that favorable and unfavorable results are related to personal effort devoted and appropriate beliefs. Given that I mainly focus on the logic of the "imagined order", I will not pay special attention to the implementation of new management models in different areas, or to the possible strategies of resistance.

\section{EXCELLENCE OF THE END USER}

In TQM literature excellence is not clearly distinguished from quality. Excellence and quality belong to the same conceptual register, and are in a teleological relationship - the purpose of quality improvement is to achieve excellence. Excellence is the motivating ideal which stimulates the members of a collective to improve quality, but is also the top result of endeavors to harmonize work organization, of its organic structuring and of constant dedication to the achievement of ideals (cf. Meško Štok et al. 2010: 307-308). Excellence, being a virtue, should be cultivated and rewarded, and is achieved relative to the overall quality attained. Although the current ideal of excellence is of corporate origin, its strength lies in the fact that it assumed the place and the role of the earlier excellence ideal espoused in the humanities and the western culture, i.e. the virtues of individual superiority and uniqueness. However, while the traditional ideal of excellence was a somewhat alienating category that an individual realized in the symbolic universe of modernity despite commonly-accepted norms and regardless of them, the more recent idea is the effect of de-alienation of economics and other areas of human activity such as culture and politics (cf. du Gay 1996: 58). The currently pervasive discourse of quality/ excellence is based on the vision of an organic collective, where all the members are dedicated to a common goal. This entrepreneurial imagery reigns supreme in corporate culture, where excellence is recognized as a characteristic of a collective that has adopted a certain structure, in this case, the organic organizational structure (cf. du Gay 1996: 41).

Quality improvement procedures gradually change the type and nature of work, operationalizing the ideal of excellence created in organizational science over 30 years ago. New 
forms of organization, evaluation and funding, which are an attempt to reach the promoted ideal, present a technical and practical difficulty to many; however, the new ideal is potentially disastrous for the humanities, because the assumed value of a theorem, the "end product" of the humanities, relies on the degree of success with which the author himself/ herself is anchored in the figure of the hero of the spirit - the symbolic base of scholarship in the humanities. The aim of this text is to indicate the problems which arise when the hero of the spirit is exchanged for the end user as the dominant figure of knowledge in the humanities. The end user is an anthropomorphized symbolic focus of the new discourse, and the fulfillment of his/her wishes and needs serves as the measure of excellence. This figure is the symbolic basis that organizations rely on, trying to react to newly arising circumstances in a quick and innovative way through projects. The end user, or the "sovereign consumer", as referred to by du Gay and Salaman (1992), who can be embodied as a client, customer, consumer or even patient, becomes a dominant subject figure of entrepreneurial discourse. The current rhetoric of quality does not mention the citizen, which we can imagine as "a concentration of rights and duties in the person of an individual, within a constitutional state, under the rule of law, and within a hierarchy of laws and regulations" (Pollit and Bouckaert 1995: 6), basing its entire view of public administration on the user, i.e. "a concentration of needs and satisfactions of needs in an individual within a market situation of supply and demand of goods and services, and within a hierarchy of needs, subject to the willingness to pay" (ibid.). The end user has a stable and "sovereign" position in the discourse of total quality management, because s/he was enthroned as the main criterion of quality as early as the 1980s. In other words, quality equals customer satisfaction (cf. Šiško Kuliš and Mrduljaš 2009; Knowles 2011: 10). In corporate imagery, the end user is a discerning, self-aware, impatient and capricious entity (cf. du Gay 1996), and requires the organization striving for excellence to be constantly ready for action and problem solving. Projected needs of the end user legitimate abandoning rigid bureaucratic control for project organization. However, the end user does not belong exclusively to the world outside the organization, workers themselves, according to du Gay, also adopt user identity and behave towards themselves in a consumption-based and entrepreneurial way, trying to maximize the value of their own existence for themselves (1996: 78). The institution of the user allows the worker to intuitively understand of the logic of satisfaction and need that $s /$ he has to follow in order to be successful. The figure of the end user in the workplace ensures complete self-actualization and equalizing the world of work and life in general.

\section{THE BEAUTY OF SIMPLICITY AND THE RHETORIC OF QUALITY}

Based on these new organizational concepts, there appeared various models and methods of organizing work processes and guaranteeing the achievement of quality (such as 
TQM, $6 \mathrm{P}^{11}$ or $5 \mathrm{~S}^{12}$ ). These models may differ in nuances, but they mostly boil down to requiring leadership vision, propensity for innovation, recognizability of products and the organization and commitment of all work-process participants to the achievement of a higher level of quality. At the end of the 20th century, the race to satisfy consumer preferences prompted corporations to maintain an image of socially-desirable actors that do not endanger natural resources, that protect the rights of their employees and consumers, and that protect cultural goods (cf. Giroux and Landry 1998). As a result of all this, quality changed from an operational and economic into a holistic term that successfully integrates social values. Today, we envision quality as a conceptual and organizational notion that encompasses the following characteristics: "product quality; service quality in the process of consumption; a fair relationship towards employees; a fair relationship towards the government; compliance with the laws, morals and customs, environmental protection and general safety in the process of production and consumption of the product" (Gašparović as cited in Funda 2008: 12).

The vagueness of the concept of quality and its openness to various interpretations is conducive to the development of a separate class of experts whose expertise is based on their proclaimed knowledge of the notion of quality and its expert interpretation, or on providing help to those who are trying to achieve quality. These consultants, the members of an emerging class in the new circumstances on the market (cf. Sennet 2006: 55-58), are becoming symbolic bearers of the abilityto set down technical requirements so as to improve the quality and excellence of someone's work performance. Consultants are unencumbered by the essence, the very nature of the business (ibid.), and act as if top results can be achieved in any business by applying the appropriate method. For instance, Samuel Wang and Simon Wu, professors of industrial and organizational engineering at the Christian University Chung Yuan in Taiwan, believe that the reason for poor success of methods like TQM in the education sector is not the fact that the method is inappropriate, as it may seem to the "biased perceptions" (Wang and Wu 2005: 2) of educational workers, but the fact that the model needs improvement. Therefore, they suggested a new and improved model based on TQM that they call H2QM - Holisticand Humanistic Quality Management.

Wang and Wu's text radiates optimism characteristic of works that deal with quality and excellence in organization. Technological optimism requires that "dealing with" boils down to the presentation of existing models and methods, their improvement and search

${ }^{11}$ The 6P concept (problem, product, promises, personal advantage, positioning, price/value) consists of implementing six steps that serve better understanding and improvement of the work process: 1) defining the customer's need or problem; 2) defining the product; 3) promises - what the product can do for the customer; 4) personal advantage - how this improves the customer's situation; 5) positioning - the benefit in relation to the competition; 6) price - what the customer must give up in terms of time or money to achieve the goal ("Service Quality and Customer Relationship Management". http://164.100.133.129: 81/ eCONTENT/Uploads/Service_Quality_and_Customer_Relationship_Management.pdf).

${ }^{12} 5 \mathrm{~S}$ is used in reference to five Japanese terms: Seiri, Seiton, Seiso, Seiketsu and Shitsuke; i.e. sort, set in order, shine, standardize and sustain. 
for new models. The esthetics fostered in quality-related texts requires simplicity and self-explanatoriness. Terms such as "mission", "vision", "culture" are used as if they were self-explanatory, and how they sound is replacement enough for their definition and explanation. This is an Adornoean jargon, where words primarily serve the purpose of calling to action, and their meaning - their "authenticity" - depends on the speaker's willingness to completely surrender to what s/he says, and guarantee it with his/her very being (Adorno 1973: 8-10). Understanding the messages, on the other hand, depends on the recipient's willingness to accept them and act in accordance with them - to devote himself/herself to the realization of the goal. The simplification which is the result of reducing the problem to the organizational dimension is a guarantee of understandability and acceptability, and simplicity itself becomes the standardof quality of the method, which is why Wang and Wu stress that they were careful not to change the initial model too much, because of "the beauty [...] of being simple" (Wang and Wu 2005: 7). Evocativeness, simplicity and recognizability are at the root of the rhetoric of excellence and quality, and ever more effective work organization methods are constantly multiplied; in addition to the already mentioned ones there are methods and programs such as: BPR, QCC, ISO 9001, QMS, TPM, CWQC, TBL, VLFM, PDCA, SPC, MBWA, SUUK, etc.

Quality-achievement procedures have taken over the world of the humanities, and are behind the imposition of new standards that institutes, faculties, and faculty departments are supposed to use in their self-perception and public representation, and within whose framework they should act. The universality and comprehensiveness of the notion of quality make it devoid of any specific meaning, making its transition into various social and organizational spheres easier. In this way, achieving quality, which started as a technological ideal, is gradually becoming a political and social ideal, which penetrates the social tissue through the state apparatus. Laws, regulations and ordinances are changing institutional science in accordance with the ideal of excellence and quality. The diffusion of the quality doctrine, as a way to legitimize the marriage between capital and the public sector, is based on entrepreneurial imagery where the ability of a quick response to market changes is the key precondition of the organization's survival, and which, in a return loop, legitimizes its success as excellent. In order to enable quick response in the public sector, new public policies encourage reducing centralized bureaucratic monitoring that ensured a dose of stability in turbulent times (cf. du Gay and Salaman 1992), encouraging, in its stead, project-based organization. The project, which became the symbol of "adaptability and contingency" (Sjöblom et al. 2013: 3) in the post-bureaucratic period, presents opportunities for quick and innovative problem-solving in public policies, but calls into question the need for long-term and continued policies (ibid.). Project organization in science rests on a specific temporality, which engineering and natural scientists are somewhat accustomed to, although they too have problems in adapting to the new circumstances such as unstable funding sources and the increasing lack of balance between work and life outside the workplace (Ylijoki 2016: 25). For scholars in the humanities and social sciences, the situation is different because individualism and long-term work on a single problem, which 
frequently took on the form of one's life's work, are some of the characteristics of their activities which vanish once they are subjected to the "project time" (ibid.).

In education and science, this situation causes a minimization of the central role that institutes and faculties play in science and research; their function is increasingly taken over by centers of excellence - organizations and research units organized around a specific research problem or working on a specific invention. Terms such as strategies, missions and visions are becoming an integral part of the package whereby universities, educational and scientific institutions present themselves to the public, with humanists and educational and scholarly institutions in the humanities performing SWOT analyses, ${ }^{13}$ setting benchmarks ${ }^{14}$ and trying to understand their own position in society, which increasingly resembles a market. "Stalinism of excellence", as it is called by Karl Kaser, led to the appearance of homo applicandus - an academic entrepreneur (Kaser 2013: 35) in the academia, adept at applying for projects and ensuring sources of funding independent of the state. In the case of the humanities, these sources are generally non-profit organizations, which is not particularly profitable (ibid.).

In order for the humanities to even start to claim its position in the new order of things, it needs to be restructured, self-evaluated and transformed in accordance with the principles of usefulness, quality and excellence, and must fulfill the organizational requirements of networking, recognizability, dissemination, etc. Theory must be subjected to method, and knowledge to utility. Problems can only be of a technical nature, and their solutions can only be sought on the technical level. In this context, usefulness becomes a mere label for form. In this framework, method replaces knowledge, and like knowledge before, it now becomes an end in itself. When the effects of the various models of quality and excellence, which are based on the presumption of their utility, are reassessed -and when this is done not based on the example of the humanities and education, but at their source, i.e. in the areas of industry and business - the obtained results may seem devastating. The results of research conducted by Helene Giroux and Sylvain Landry (1998), experts in quality and logistics, show that the application of TQM in organizing business and manufacturing organizations does not lead to an automatic improvement of operations, quality or work processes, which is usually explained by the apologists of the method as being a result of lack of enthusiasm and commitment on the part of employees and the management. What TQM does frequently result in is workplace burnout, which is what the race for excellence of performance leads to.

Giroux and Landry claim that these models, whose success is related more to the cultural ideal of constant individual development than with real economic effects, enables the dispersion of responsibility for the fate of the organization on all its employees. In short, methods like TQM are not exact (and it is unclear to what extent these are methods at all),

\footnotetext{
${ }^{13}$ Analysis of organizational strengths and weaknesses.

${ }^{14}$ Setting benchmarks, benchmarking, refers to the process of setting standards and criteria on the basis of which an organization can analyze its performance and achievements.
} 
and their endurance and acceptance are more clearly related with the strengthening of the cultural matrix that promotes the values of commitment, continued self-development and competitiveness, than with the results that can be achieved.

\section{THE USA - CREATION OF EXCELLENT EDUCATION}

In the USA excellence was traditionally perceived as a virtue of being above the average, achieved by actualizing one's individual wishes, talents and capacities that could not or should not be subjected to socially-determined expectations. Society was expected to allow everyone to develop one's own talents and personal aspirations, i.e. one's own excellence. In the last decades this ideal became the basic category of corporate and politically conservative rhetoric in the USA, with the insistence on excellence being merely an ideological tool to encourage individuals to put more effort in fulfilling the set goals (Green 1998: 26-28).

Corporate excellence is based on the idea that people, their knowledge and motivation and their "adaptation" to the current market demands are the basis of economic success or lack there of. This explanation became the basic mantra used to explain the economic crisis that hit the USA in the early 1980s. ${ }^{15}$ In accordance with this logic - given that the human factor failed - the entire blame for the crisis was put on the education system that produced poorly-qualified workforce, and the only logical solution was to undertake a comprehensive educational reform. Although some very serious studies showed that the poor results of the American economy had nothing to do with education, but with the decisions made on the national level, "excellence reform" (Berube 1998: 93-95) was started. This reform, unfortunately, did away with the programs of the previous two reforms, ${ }^{16}$ which strived to develop critical thinking and make high-quality education available to poor members of the society, thus preparing them for the realization of their own individual excellence. The aim of the "excellence reform" was to raise the standard of education and to help the best pupils and students to compete in the global market. The reform was marked by a distrust of public education, and its privatization by corporations (ibid.).

Before the reform, public education in the USA represented a symbolic place of hope for the working class (Aronowitz and Giroux 2003: IX). It gave the gifted and persistent members of the working class access to administrative and academic jobs, as well as training for a profession that would make it easier for them to enter the middle class. Because of its supposed non-effectiveness, it was under constant attack by the American

${ }^{15}$ Sharp decline in gross domestic product, increase in trade deficit and internal debt nearing one billion (Berube 1998: 93).

${ }^{16}$ In American education, the beginning of the twentieth century was marked by the so-called Progressive Movement in Education, Equity Reform emerged in the second half of the century, and the century ended with the "excellence reform" (Berube 1998). 
radicals and conservatives. The usual conservative objection to public education, according to Aronowitz and Giroux (2003: X), was that it did not prepare students for "real life", which, in a conservative perspective, meant prioritizing corporate to educational needs. Moreover, the "age of money" started, where the success of academic disciplines depended on their ability to offer: "a promise of money [...] a knowledge of money [...] [or] a source of money" (Engell and Dangerfield 1998: 52).

The corporate ideal of excellence took over the idea of complete actualization of personal talents and aspirations, and the self-actualization was no longer to be realized in the social context, but in the business context: "paid work (no matter how 'objectively' alienated, deskilled or degraded it may appear to social scientists) [is] an essential element in the path to self-fulfilment and provides the a priori that links together work and non-work life" (du Gay 1996: 65). According to David E. Guest (1990), this ideal of corporate excellence proved to be irresistibleto the Americans because it captured the essence of the American dream of self-realization and growth. However, Guest fails to notice the break noticed by Aronowitz and Giroux (2003), Green (1998) and Berube (1998), whereby the political society transforms into a corporate society, and where citizens are replaced by consumers.

\section{EXCELLENCE IN THE HUMANITIES AND THE HERO OF THE SPIRIT}

In the humanities of the premodern era, excellence was traditionally perceived as an individual quality that referred to the mental capabilities and spiritual virtues that were, at certain points in time, considered noble as well ascentral. In the Middle Ages, the soul open to divine grace was considered a key and necessary virtue, whereas in the modern period philanthropy and cosmopolitanism took its place. According to Andrea Robiglio (2006), individual spiritual and mental constitution, and embodied virtues were the essential assumptions to do philosophy, and constituted an important part of philosophical thought until Hegel, when they get slowly lost from the horizon of philosophic thinking. In the Middle Ages, a philosopher's excellence was considered in the light of the idea of nobility. At this time, alongside the political and religious concept of nobility, a philosophical concept of nobility appears, rooted in the idea of nobility as intellectual virtue based on Aristotle's ideas concerning perfection and heroism. The image of the philosopher based on these ideas takes on the coherent form of a thinker "as a man from the upper classes, committed (though passively) to his community, mastering his passions (his discretio is never overridden by passions), who seeks glory by seeking philosophical truth" (Robiglio 2006: 235). Aspiring for honor and glory become more pronounced and desirable characteristics of a philosopher, and intellectual nobility becomes a separate value which would, in the Renaissance, be acquired by coming into conflict with religious and state authorities (Robiglio 2006).

In the modern age, the figure of an intellectual inherited the aura of a renaissance thinker who completely independently surrenders to the quest for the truth in order to 
achieve glory, which is how the myth of a "great man" (Bowman 2005: 4) was born - an individual who acts alone, changing the course of history and founding his/her own school of thought. Although this hero of the spirit, represented as a figure whose Promethean hybris enables him/her to understand the sublime and bring it to consciousness, has been ridiculed in philosophy itself (cf. Marks and Engels 1964; Nietzsche 2004: 125), it is the basis of how the humanities operate. The expectation set before the intellectual - to continually confirm his/her intellectual authenticity and independence - led to a specific type of scholarly production, where there is a clear critical edge directed against the system of power and fellow intellectuals. Anti-authoritarianism of the hero of the spirit was in accordance with the enlightenment project which, to berealized, needed a rational subject - a citizen, subject exclusively to the laws of the mind and independent of the metaphysical authority and the authority of tradition (cf. Kalanj 1994). The humanist intellectual in the modern era thus starts to embody the very ideal of modern subjectivity. The figure of a rational individual, who uses conflict, dispute and criticism to assume his/her own place on the humanist symbolic horizon, would earn his/her standing through the game of argumentation and counter-argumentation, proving and denying the rationality of conflicting views. This symbolic context places a burden on an individual that leads to an integration of the personal and the professional, and as opposed to the natural scientific theories which strive for a completely objective validation independent of personal inclinations, humanities are frequently seen through their authors, and vice versa. ${ }^{17}$ Thus, for instance, active collaboration of physicists Philipp Lenard and Johann Stark with the Nazi regime in no way influenced the later understanding and interpretation of their work on the cathode ray tube or the Stark effect. ${ }^{18}$ As opposed to this, Heidegger's flirtation with Nazism is a constantly appearing key for the interpretation and the disqualification of his philosophemes: "Heidegger's involvement with National Socialism - which was of the order of deep-seated, existential commitment - was far from being an adventitious, merely biographical episode. Instead, it was rooted in the innermost tendencies of his thought" (Wolin 1992: 66).

\section{CONCLUSION}

The requirement to subject the humanities to the logic of usefulness and utility in the era of excellence contributes to a drama between the humanities and the "rationalization of the system", which plays out as a conflict between the requirement for rationalization,

\footnotetext{
17 The integration of what is intellectual and what is lived, the demand for action that accompanies thinking, was radically achieved by Socrates, who paid for his views with his life. Most philosophers after him preferred to solve their conflict with secular and church authorities by exile (cf. Mikulić 2008). Plato's writings on Socrates, according to John Peterman (2008), promote a new type of heroism which is an attempt to test godlike qualities of reason.

${ }^{18}$ Stark effect refers to a phenomenon which appears when atoms and molecules are exposed to an external electric field.
} 
usefulness and utility and the struggle for the right to non-utilitarian scholarly activity and production - the right to "slow science" (Kaser 2013: 35). Roles divided in this way heighten the impression that the humanities are in fact fighting for their right to be useless, to nurture knowledge as an end in itself, because they, alas, have trouble in making their area of expertise processed in a way that would improve productivity and the quality of the work itself. There is a different view too, according to which humanities are simply not practical, and in a society which is turned exclusively to the practical and utilitarian, they must disappear. Insisting on either of these two perspectives means losing sight of the intrinsic evaluative orientation inherent in the corporate ideal of excellence. The - by now global - project of excellence has none of the cynicism that is frequently attributed to it. On the contrary, it consists of good intentions. Sincerity and enthusiasm which gush out of the TQM literature really indicate that managers want to create a workplace that is full of opportunities and incentives for personal growth (cf. Guest 1990: 392), and are willing to make the effort to help us in the humanities to achieve excellence, fulfillment and superior quality. However, the humanities and TQM speak two different languages. The humanities do not speak the language of needs and their satisfaction. Its symbolic basis - the figure of the hero of the spirit and the independent intellectual - is not conducive to understanding the needs and wishes of the contemporary consumer. In this sense, the controversies about the usefulness and utility of the humanities are somewhat futile. The question is not whether the humanities are practical - but whether they are satisfactory. Can the humanities deliver, and, very importantly, can they deliver on time. "On-time delivery", according to Ylva Hasselberg (2016), becomes the dominant characteristic of academic work in the project context. Scholars who are late cause the investors' mistrust, theories and research are directed towards issues which can be solved more easily, and more ambitious theoretical endeavors are avoided so as to minimize the possibility for the project to end without results or with poor results (ibid.). The struggle to attract funding through projects determines the shape and content of research, because the criteria of time and organization become foremost. When this happens, the affective relationship towards one's own work decreases, which can lead to a professional identity crisis in the humanities: "Can there be scholarship worthy of the name that does not involve a strong emotional relationship with one's own questions and work [...] Can the question 'What can I obtain money to do?' really supersede the question 'What is worth doing?' without what we do becoming meaningless?" (Hasselberg 2016: 24).

The humanities in their essence does not enable clear completion or conclusion of a theoretical or a critical endeavor. Questions and problems remain open, and new ones constantly appear. Ivan Focht's words that philosophy has not answered a single question since its very beginning (Focht 1972: 1) can be applied to the whole of the humanities. The time of humanists is that of "long duration", and their symbolic space is characterized by a split, and cannot become complete. Completeness and wholeness realized by a sovereign consumer is unattainable for them. The addressee of the humanities is still a citizen whose freedom and independence are based in the social contract. But the current 
basis of freedom and autonomy is the choice made by the end user in the market (cf. Corner and Harvey 1991: 1).

However, the humanities do have something in common with the corporate ideal of excellence that presumes dedication to the project and complete realization of personal potentials in one's job, but this, I believe, decreases their ability to criticize the ideal. The figure of the "hero of the spirit" requires complete involvement of a person in his/her own "humanist project". We do not have to strive to realize the corporate ideal, because our very activity, on the symbolic level, presumes that we have already adopted it. However, how can one who is already dedicated to his/her job criticize the ideology of dedication and fulfillment? It is this very dedication that represents a blind spot of a critical perspective in the humanities, which makes it difficult to achieve the distance from the work ethos that is based on the ideology of excellence. For instance, Paul du Gay, one of the more prominent critics of the new organizational models, who is a cultural studies sociologist, is trying to affirm certain traditional bureaucratic virtues as the counter-ideal to the corporate vision of the workplace (2005). He emphasizes certain positive aspects of bureaucratic organization, and referring back to Thomas Hobbes and Max Weber, claims that we should not see the bureaucrat as a figure of a servant of the system devoid of ideas, as much as a person who is trying to serve society, citizens, and who is dedicated to procedures that ensure that these same citizens are treated equally before the law. Attempts like du Gay's, where problems and issues from one period are attempted to be addressed using solutions belonging to a previous period, rarely succeed. Particularly because, TQM-like organizational models could be, for instance, seen as an attempt to better fulfill the ideal characteristic of the previous - bureaucratic - organizational structure. TQM-like ideology and work procedure are a more consistent way to embody - perhaps even embody without limits - the ideal of dedication and commitment to a goal, and the willingness to serve the citizen (who has in the meantime turned into the user). Thanks to the disappearance of bureaucratic boundaries the time required to respond to the needs of various users of the system is shortened, and rather than serving society as an abstract ideal, the former bureaucrat can now, through organic participation in his/her own organization, directly fit into the wider collective.

It would be equally futile to insist that the humanities return to the old symbolic foundations, as a safe haven, where our activity and work would not be contaminated by the new circumstances. Because now, dedication to one's activities, which we perceive as one of the foundations of the humanist calling - is now maximally realized on the level of the system. The adequate criticism of corporate discourse is out of our reach because, essentially, we start from the very same premises as corporate discourse. It is only through criticizing excellence as such, i.e. the very value of excellence, which includes facing one's own ideal of excellence and disclosing its ultimate effects, can we possibly criticize the predominant cultural values - dedication and commitment.

Perhaps it is time to break off with the heritage of the hero of the spirit and start alienating from what we are doing. I do not mean start working poorly, but making it clear that it 
is work, and not a spontaneous flash of our inner self which is compensation enough for the non-fulfillment of some basic life needs like free time, sun, air or play. The humanities is work, and although working with one's colleagues frequently helps, it is not synergetic work, but largely solitary, and frequently tedious. And complete dedication to work - no matter how much this work may correspond with our affinities - will never make us fulfilled and happy. And, even if we do not get completely involved in this work, even if we feel terrible while doing it, this does not mean that we will do a poor job.

Perhaps the best example of such sincerity is the afterword of, I can venture to say, the excellent book Male Phantasies by Klaus Theweleit (1989), where he informs the reader that the book is finished not because he thought it out completely, but because of deadlines and lack of money. He goes on to say how terrible it was to work on the text, that he was absent from the family life and left the entire burden on his wife, and concludes that such things should not be done often, because they are "not worth the effort" (Theweleit 1989: 495). So, guided by his example, I will now end this text, and rather than pretending that it has been completely thought out, I will admit that this is the end simply because Narodna umjetnost does not accept texts longer than 8000 words.

\section{REFERENCES AND SOURCES}

Adorno, Theodor W. 1973. The Jargon of Authenticity. Evanston: Northwestern University Press.

Aronowitz, Stanley and Henry A. Giroux. 2003. Education Under Siege [electronic resource]. The Conservative, Liberal, and Radical Debate over Schooling. London: Taylor \& Francis e-Library.

Baver, Veronika and Wanda Vrasti. 2016. “Od diktata izvrsnosti prema politici predanosti”. Slobodni Filozofski. Available at: http://slobodnifilozofski.com/2016/01/veronika-bauer-i-wanda-vrasti-od.html (accessed 12 February 2016).

Berube, Maurice M. 1998. American School Reform. Progressive, Equity, and Excellence Movements, 1883-1993. Westport: Praeger Publishers.

Bowman, Charles E. 2005. "The History and Development of Gestalt Therapy". In Gestalt Therapy. History, Theory and Practice. Ansel L. Woldt and Sarah M. Toman, eds. Thousand Oaks, London, New Delhi: Sage Publications, 3-20. [https://doi.org/10.4135/9781452225661.n1]

Corner, John and Sylvia Harvey. 1991. "Introduction. Great Britain Limited". In Enterprise and Heritage: Crosscurrents of National Culture. John Corner and Sylvia Harvey, eds. London, New York: Routledge.

Dolaček-Alduk, Zlata, Vladimir Sigmund and Sanja Lončar-Vicković. 2008. "Osiguranje kvalitete visokog obrazovanja u europskom obrazovnom prostoru". Tehnički vjesnik 15/1: 39-44.

du Gay, Paul. 1996. Consumption and Identity at Work. London, Thousand Oaks, New Delhi: Sage Publications.

du Gay, Paul. 2000. "Enterprise and Its Futures. A Response to Fournier and Grey". Organization 7/1: 165: 183.

du Gay, Paul. 2005. "Bureaucracy and Liberty. State, Authority, and Freedom. In The Values of Bureaucracy. Paule Du Gay, ed. New York: Oxford University Press, 41-61.

Du Gay, Paul and Graeme Salaman. 1992. "The Cult[ure] of the Customer". Journal of Managament Studies 29/5: 633. 
Engell, James and Anthony Dangerfield. 1998. "The Market-Model University. Humanities in the Age of Money”. Harvard Magazine 100/5: 48-55.

Focht, Ivan. 1972. Uvod u estetiku. Sarajevo: Zavod za izdavanje udžbenika.

Funda, Dragutin. 2008. Potpunou pravljanje kvalitetom u obrazovanju. Zagreb: Kigen.

Giroux, Helene and Sylvain Landry. 1998. "Schools of Thought In and Against Total Quality". Journal of Managerial Issues 10/2: 183-203.

Green, Joe. 1998. "Two Dogmas of Excellence". Journal of Philosophy and History of Education 48: 25-39.

Guest, David E. "Human Resource Management and the American Dream". Journal of Management Studies 27/4: 377-397. [https://doi.org/10.1111/j.1467-6486.1990.tb00253.x]

Hasselberg, Ylva. 2016. "Money Has no Odour". In Thinking Ahead. Research, Funding and the Future. Jenny Björkman and Björn Fjćstad, eds. Gothenburg, Stockholm: Makadam, 15-26.

Houston, Archester and Steven L. Dockstader. 1997. Total Quality Leadeship. A Primer. Washington: Department of the Navy TQM Office.

Kalanj, Rade. 1994. Modernost i napredak. Zagreb: Antibarbarus.

Kaser, Karl. 2013. "The Creation of a New Figure in Academia - The Homo Applicandus". Glasnik etnografskog instituta SANU 61/2: 33-39.

Katunarić, Vjeran. 2013. Svjetski antibarbarus. O uzrocima propasti bivšeg i nadolaskanovog socijalizma. Zagreb: Društvo Povijest izvan mitova.

Knowles, Graeme. 2011. Quality Management. Graeme Knowles \& Bookboon.com. Available at: http://www.znrfak.ni.ac.rs/SERBIAN/010-STUDIJE/OAS-3-2/PREDMETI/III\%20GODINA/316KOMUNALNI\%2OSISTEMI\%20I\%2OZIVOTNA\%2OSREDINA/SEMINARSKI\%2ORADOVI/2014/ S175\%20-\%20S200.pdf (accessed 20 October 2016).

Lamont, Michèle. 2009. How Professors Think. Inside the Curious World of Academic Judgment. Cambridge: Harvard University Press. [https://doi.org/10.4159/9780674054158]

Lévi-Strauss, Claude. 1963. Structural Anthropology. New York: Basic Books, Inc.

Lynch, James, Celia Modgil and Sohan Modgil. 2013. "The Dilemma for Cultural Diversity”. In Cultural Diversity And The Schools, 3. Equity or Excellence: Education And Cultural Production. James Lynch, Celia Modgil and Sohan Modgil, eds. London, New York: Routledge, 275-282.

Marks, Karl and Fridrih Engels [Marx, Karl and Friedrich Engels]. 1964. Nemačka ideologija. Kritika najnovije nemačke filozofije u licu njenih predstavnika Fojerbaha, B. Bavera i Štirnera i nemačkoga socijalizma u njegovim različitim prorocima. Beograd: Kultura.

Matei, Lucica and Corina-Georgiana Lazăr. 2011. "Quality Management and the Reform of Public Administration in Several Statesin South-Eastern Europe. Comparative Analysis". Theoretical and Applied Economics 18/4: 65-98.

Meško Štok, Zlatka, Mirko Markič, Andrej Bertoncelj and Maja Meško. 2010. "Elements of Organizational Culture Leading to Business Excellence". Zbornik radova ekonomskog Fakulteta u Rijeci: časopis za ekonomsku teoriju i praksu 28/2: 303-318.

Nietzsche, Friedrich Wilhelm. 2004. Uz genealogiju morala. Zagreb: AGM.

"Nove boje znanja: strategija obrazovanja znanosti i tehnologije". 2015. Zagreb: Ministarstvo znanosti, obrazovanja i sporta. Available at: http://www.novebojeznanja.hr/UserDocslmages/datoteke/KB_ web.pdf (accessed 25 September 2016).

Oslić, Ivica. 2008. Kvaliteta i poslovna izvrsnost. Zagreb: M. E. P. Consult.

Peterman, John. 2008. On Ancient Philosophy. Belmont, CA: Thomson Wadsworth. 
Pollit, Christopher and Geert Bouckaert. 1995. "Defining Quality". In Quality Improvement in European Public Services. Concepts, Cases and Commentary. Christopher Pollit and Geert Bouckaert, ed. London, Thousand Oaks, New Delhi: Sage Publications, 3-19.

Pollit, Christopher and Geert Bouckaert. 2004. Public Management Reform. A Comparative Analysis. Oxford: Oxford University Press.

"Promemorija odabira najuspješnijih znanstvenih novaka". 2013. Available at: http://www.public.mzos. hr/fgs.axd?id=19630 (accessed 25 February 2016).

Robiglio, Andrea. 2006. "The Thinker as a Noble Man (bene natus) and Preliminary Remarks on the Medieval Concepts of Nobility". Vivarium 44/2-3: 205-247. [https://doi. org/10.1163/156853406779159428]

Sennet, Richard. 2006. The Culture of the New Capitalism. New Haven: Yale University Press.

Service Quality and Customer Relationship Management. Bangalore: Rai Technology University. Available at: http://164.100.133.129:81/eCONTENT/Uploads/Service_Quality_and_Customer_Relationship_Management.pdf (accessed 20 October 2016).

Sisek, Boris. 2012 "Poslovna izvrsnost i stakeholderski pristup poduzeću". In Računovodstvo i menadžment, 13. međunarodna znanstvena i stručna konferencija, Zbornik radova s međunarodne znanstvene i stručne konferencije, 2. Vinko Belak, ed. Zagreb: Hrvatski računovođa, 207-216.

Sjöblom, Stefan, Karl Löfgren and Sebastian Godenhjelm. 2013. "Projectified Politics - Temporary Organizations in a Public Context - Introduction to the Special Issue". Scandinavian Journal of Public Administration 17/2: 3-12.

"Strateški plan za razdoblje 2014.-2016. 2013b. Available at: http://www.public.mzos.hr/fgs. axd?id=20740 (accessed 25 February 2016).

Suarez, Gerald J. 1992. Three Experts on Quality Management. Philip B. Crosby, W. Edwards Deming, Joseph M. Juran. Arlington, VA: Department of the Navy TQL Office.

Šiško Kuliš, Marija and Zvonko Mrduljaš. 2009. "Gurui kvalitete”. Tehnički vjesnik 16/3: 71-78.

Theweleit, Klaus. 1989. Male Fantasies, 2. Minneapolis: University of Minnesota Press.

Wang, H. Samuel and Simon Wu. 2005. "H2QM: TQM Model for Education with Humanistic Emphasis". Available at: http://www.eoq.org/fileadmin/user_upload/Documents/Congress_proceedings/Turkey_2005/Proceedings/058_H. Samuel_Wang.pdf (accessed 20 October 2016).

Wolin, Richard. 1992. The Politics of Being. The Political Thought of Martin Heidegger. New York: Columbia University Press.

Ylijoki, Oili-Helena. 2016. "Projectification and Conflicting Temporalities in Academic Knowledge Production". Theory of Science 1: 7-26. 


\section{KRITERIJI IZVRSNOSTI U HUMANISTICI}

Izvorno je izvrsnost u humanistici shvaćena kao agonistička i patricijska vrlina koja se oslanjala na prometejski hybris subjekta humanistike. Taj je heroj duha imao u sebi utjeloviti najviše ljudske vrline (shvaćene kroz liberalno-civilizacijsku prizmu): kozmopolitizam, liberalizam, filantropiju. No trenutno su značenje i upotreba termina izvrsnost određeni idejom kvalitete razvijenom u organizacijskim znanostima, na koju se, osim korporacija, pozivaju i vlade i ministarstva. Ta ideja počiva na pretpostavci da kvaliteta proizvoda ovisi prvenstveno o organizaciji radnih procesa. Zbog toga se i humanistici kao temeljni kriterij izvrsnosti nameće onaj ispunjavanja organizacijskih zahtjeva poput: zahtjeva za umreženošću, za prepoznatljivošću, za diseminacijom itd. $U$ takvoj je situaciji heroj duha ustupio mjesto krajnjem korisniku kao dominantnoj figuri na koju se nadovezuje retorika korporacijske izvrsnosti. Humanistika se tako zatiče u poziciji otežane komunikacije s prevladavajućom društvenom paradigmom oblikovanom prema korporacijskom uzoru.

Ključne riječi: heroj duha, humanistika, izvrsnost, krajnji korisnik 